Article

\title{
Exploring the Potential of Meyerozyma guilliermondii on Physiological Performances and Defense Response against Fusarium Crown Rot on Durum Wheat
}

\author{
Zayneb Kthiri ${ }^{1, *(\mathbb{D})}$, Maissa Ben Jabeur ${ }^{1}\left(\mathbb{D}\right.$, Fadia Chairi ${ }^{2}$, Camilo López-Cristoffanini ${ }^{2}$ (D), \\ Marta López-Carbonell ${ }^{2}$, Maria Dolores Serret ${ }^{2,3}$, Jose Luis Araus ${ }^{2,3}{ }^{\mathbb{D}}$, Chahine Karmous ${ }^{1}\left(\mathbb{D}\right.$ and Walid Hamada ${ }^{1}$ \\ 1 Laboratory of Genetics and Plant Breeding, National Institute of Agronomy of Tunis, 43, Av Charles Nicolle, \\ Tunis 1082, Tunisia; maissa.benjabeur@hotmail.com (M.B.J.); karmouschahine@gmail.com (C.K.); \\ w_hamada@yahoo.com (W.H.) \\ 2 Section of Plant Physiology, University of Barcelona, 08028 Barcelona, Spain; fadia.chairi@hotmail.fr (F.C.); \\ camilo.lopez.cr.puc@gmail.com (C.L.-C.); mlopez@ub.edu (M.L.-C.); dserret@ub.edu (M.D.S.); \\ jaraus@ub.edu (J.L.A.) \\ 3 AGROTECNIO (Center of Research in Agrotechnology), University of Lleida, 25198 Lleida, Spain \\ * Correspondence: zayneb.kthiri@gmail.com; Tel.: +216-53-556-6 10
}

Citation: Kthiri, Z.; Jabeur, M.B.; Chairi, F.; López-Cristoffanini, C.; López-Carbonell, M.; Serret, M.D.; Araus, J.L.; Karmous, C.; Hamada, W. Exploring the Potential of Meyerozyma guilliermondii on Physiological Performances and Defense Response against Fusarium Crown Rot on Durum Wheat. Pathogens 2021, 10, 52 https://doi.org/10.3390/pathogens 10010052

Received: 15 December 2020 Accepted: 28 December 2020 Published: 8 January 2021

Publisher's Note: MDPI stays neutral with regard to jurisdictional clai$\mathrm{ms}$ in published maps and institutional affiliations.

Copyright: () 2021 by the authors. Licensee MDPI, Basel, Switzerland. This article is an open access article distributed under the terms and conditions of the Creative Commons Attribution (CC BY) license (https:// creativecommons.org/licenses/by/ $4.0 /)$.

\begin{abstract}
Coating seeds with bio-control agents is a potentially effective approach to reduce the usage of pesticides and fertilizers applied and protect the natural environment. This study evaluated the effect of seed coating with Meyerozyma guilliermondii, strain INAT (MT731365), on seed germination, plant growth and photosynthesis, and plant resistance against Fusarium culmorum, in durum wheat under controlled conditions. Compared to control plants, seed coating with M. guilliermondii promoted the wheat growth (shoot and roots length and biomass), and photosynthesis and transpiration traits (chlorophyll, $\phi$ PSII, rates of photosynthesis and transpiration, etc.) together with higher nitrogen balance index (NBI) and lower flavonols and anthocyanins. At 21 days post infection with Fusarium, M. guilliermondii was found to reduce the disease incidence and the severity, with reduction rates reaching up to $31.2 \%$ and $30.4 \%$, respectively, as well as to alleviate the disease damaging impact on photosynthesis and plant growth. This was associated with lower ABA, flavonols and anthocyanins, compared to infected control. A pivotal function of M. guilliermondii as an antagonist of F. culmorum and a growth promoter is discussed.
\end{abstract}

Keywords: Meyerozyma guilliermondii; Fusarium culmorum; durum wheat; growth promotion; physiological traits; induced defense response

\section{Introduction}

In Tunisia, durum wheat is, by extension, the main herbaceous crop, covering over $40 \%$ of the cereal-producing areas [1]. However, durum wheat yield is affected by the harmful effects of various fungal pathogens causing drastic losses, up to $26 \%$ for durum under fusarium foot and root rot disease [2]. F. culmorum is the most reported Fusarium crown rot (FCR) pathogen $[3,4]$. The fungus infects seeds since initial growth stages leading to a decrease in seed germination and emergence rate. Moreover, the infections might occur in roots, root crown and stem tissues [5]. The control of F. culmorum by chemical fungicides [6] showed low efficiency due in part to the development of fungicide resistance as well as harmful environmental impact. Thus, novel and integrated management approaches against F. culmorum have been developed and tested [7]. In fact, seed priming using biostimulants, as seed coating agents, was used to induce germination, abscisic acid to improve emergence of seedlings [8-10], and to induce mechanisms of plant disease resistance [11].

Upon infection and/or treatment with biostimulants, plant often activated a highly coordinated biochemical and structural mechanisms of defence, including hormones, 
sugars and phenolic compounds to inhibit pathogen proliferation [12]. Besides, defence mechanisms against plant disease are built to restrain fungal pathogens through the accumulation of phenolics compounds involved in cell walls lignification [13]; The use of yeasts constitutes a new promising biostimulant approach to improve disease resistance and plant growth. These endophytic yeasts exude a range of secondary metabolites (phenols, flavonoids, abscisic acid (ABA), indoleacetic acid (IAA), etc.) to help the plant to overcome stress conditions [14].

Photosynthesis generates NADPH, ATP, and carbohydrates. These resources are used for the biosynthesis of many important compounds, such as primary metabolites, antimicrobial compounds, and defence-related hormones, such as jasmonic, salicylic and abscisic acids, ethylene, and antimicrobial compounds [15]. The key steps in the biosynthesis of defence-related hormones and their precursors take place in the chloroplast. Further, chloroplasts are major generators of reactive oxygen species (ROS) and nitric oxide, and a site for calcium signalling. These signalling molecules are important to plant defence as well [15]. However, photosynthetic activity is deeply affected under biotic stressors such as F. verticillioides on maize [16]. In the case of Fusarium head blight, it causes a significant reduction in the net photosynthesis rate of the flag leaf of wheat plants [17].

In recent years, yeast-induced plant resistance has been considered a potential approach to control plant pathogens; this is the case, for example, of Pichia guilliermondii strain Z1 against citrus blue mould on citrus [17], P. guilliermondii against Rhizopus nigricans on tomato fruit [18] and M. guilliermondii on rice blast, cabbage black leaf spot, and tomato bacterial wilt diseases [19]. However, to date, no reports exist on the effects of these yeasts on promoting disease tolerance in durum wheat. The present investigation constitutes the first study on the effect of seed coating with $M$. guilliermondii on plant growth of durum wheat, and on promoting defence in response to F. culmorum infection.

\section{Results}

2.1. Effect of Seed Coating with M. guilliermondii and Infection with F. culmoum on Seed Germination and Seedling Growth of Wheat

Results showed that coating with $M$. guilliermondii significantly and positively affected all measured parameters as rate of germination $(p<0.01)$, biomass $(p \leq 0.05)$, and root and shoot length $(p \leq 0.001)$ (Table 1$)$. However, the infection with F. culmorum significantly affected only the root and shoot length and biomass $(p \leq 0.001)$.

Table 1. Effect of seed coating with M. guilliermondii on wheat growth parameters, under non-infected and infected conditions by F. culmoum. Values are means $\pm \mathrm{SD}$ of three replicates.

\begin{tabular}{|c|c|c|c|c|c|c|c|c|c|c|c|c|c|}
\hline \multicolumn{2}{|c|}{ Traits } & \multicolumn{3}{|c|}{ Germination \% } & \multicolumn{3}{|c|}{ Shoot Length (cm) } & \multicolumn{3}{|c|}{ Root Length (cm) } & \multicolumn{3}{|c|}{ Biomass (g) } \\
\hline & & $\begin{array}{c}\text { Non- } \\
\text { Infected }\end{array}$ & Infected & $\begin{array}{l}\text { DR } \\
(\%)\end{array}$ & $\begin{array}{c}\text { Non- } \\
\text { Infected }\end{array}$ & Infected & $\begin{array}{l}\text { DR } \\
(\%)\end{array}$ & $\begin{array}{c}\text { Non- } \\
\text { Infected }\end{array}$ & Infected & $\begin{array}{l}\text { DR } \\
(\%)\end{array}$ & $\begin{array}{l}\text { Non- } \\
\text { Infected }\end{array}$ & Infected & $\begin{array}{l}\text { DR } \\
(\%)\end{array}$ \\
\hline \multicolumn{2}{|c|}{ Control } & $\begin{array}{c}46.7 \pm \\
9.5\end{array}$ & $\begin{array}{c}26.7 \pm \\
9.2\end{array}$ & 42.8 & $\begin{array}{c}52.0 \pm \\
1.6\end{array}$ & $\begin{array}{c}35.5 \pm \\
0.4\end{array}$ & 31.73 & $\begin{array}{c}24.0 \pm \\
0.2\end{array}$ & $\begin{array}{c}15.9 \pm \\
0.8\end{array}$ & 33.75 & $\begin{array}{c}9.3 \pm \\
05\end{array}$ & $\begin{array}{c}4.6 \pm \\
0.6\end{array}$ & 50.53 \\
\hline \multicolumn{2}{|c|}{ M. guilliermondii } & $\begin{array}{c}93.3 \pm \\
12.2\end{array}$ & $\begin{array}{c}70.0 \pm \\
9.4\end{array}$ & 24.97 & $\begin{array}{c}73.6 \pm \\
1.0\end{array}$ & $\begin{array}{c}54.5 \pm \\
0.4\end{array}$ & 25.95 & $\begin{array}{c}40.6 \pm \\
0.3\end{array}$ & $\begin{array}{c}33.1 \pm \\
0.5\end{array}$ & 18.47 & $\begin{array}{c}10.8 \pm \\
0.7\end{array}$ & $\begin{array}{c}7.4 \pm \\
0.7\end{array}$ & 31.48 \\
\hline \multirow{3}{*}{ ANOVA } & $\begin{array}{l}\text { Infection } \\
\text { (I) }\end{array}$ & & $408 \mathrm{~ns}$ & & \multicolumn{3}{|c|}{$181.7^{* * *}$} & \multicolumn{3}{|c|}{$63.02 * * *$} & \multicolumn{3}{|c|}{$27.90^{* * *}$} \\
\hline & $\begin{array}{l}\text { Coating } \\
\text { (C) }\end{array}$ & \multicolumn{3}{|c|}{$3675^{* *}$} & \multicolumn{3}{|c|}{$317.2^{* * *}$} & \multicolumn{3}{|c|}{$130.02^{* * *}$} & \multicolumn{3}{|c|}{$3.96 *$} \\
\hline & $\mathrm{C} \times \mathrm{I}$ & \multicolumn{3}{|c|}{$8 \mathrm{~ns}$} & \multicolumn{3}{|c|}{$4.9 \mathrm{~ns}$} & \multicolumn{3}{|c|}{$12.20^{* *}$} & \multicolumn{3}{|c|}{$1.14 \mathrm{~ns}$} \\
\hline
\end{tabular}

The sum square values with statistical significance are shown (ns: non-significant, $\left.{ }^{*}: p<0.05 ;{ }^{* *}: p<0.01 ;{ }^{* * *}: p<0.001\right)$. DR: decrease from non-infected, SD: stander deviation.

Under non-infected conditions, seed coating with M. guilliermondii increased the germination rate of seeds up to $93.3 \%$ compared to control seeds that reached only $46.7 \%$. 
Moreover, it increased the shoot and root length and plant biomass (Table 1). In control plants, the infection with F. culmorum induced a reduction in germination rate $(\mathrm{DR}=42.8 \%)$, shoot length (31.7\%), root length (33.8\%), and in plant biomass $(50.5 \%)$. In plants treated with $M$. guillermondii, the infection resulted in a lesser reduction of germination rate $(\mathrm{DR}=24.9 \%)$, shoot length $(25.9 \%)$, root length $(18.4 \%)$, and of plant biomass $(31.4 \%)$, compared to infected control (i.e., untreated) plants.

\subsection{Effect of Seed Coating with M. guilliermondii on the Incidence and Severity of Fusarium Crown Rot}

A significant increase over the time was showed for both the disease incidence and severity (Figure 1); basing on the symptoms caused by the endophytic fungus F. culmorum on wheat plants at 14, 21 and 28 das. At 14 das, we observed a slight significant difference in the disease incidence and severity $(p<0.05)$ between $M$. guilliermondii- treated plants and control plants. At 21das, the effect of M. guilliermondii in controlling the Fusarium crown rot development was more remarkable compared to the control plants $(p<0.01)$. The impact of the seed coating with M. guilliermondii was further confirmed at 28 das, depicted by significant lower incidence and severity on the crowns, compared to control $(p<0.01)$, with reduction rates reaching up to $31.18 \%$ and $30.43 \%$, respectively (Figure 1 ).

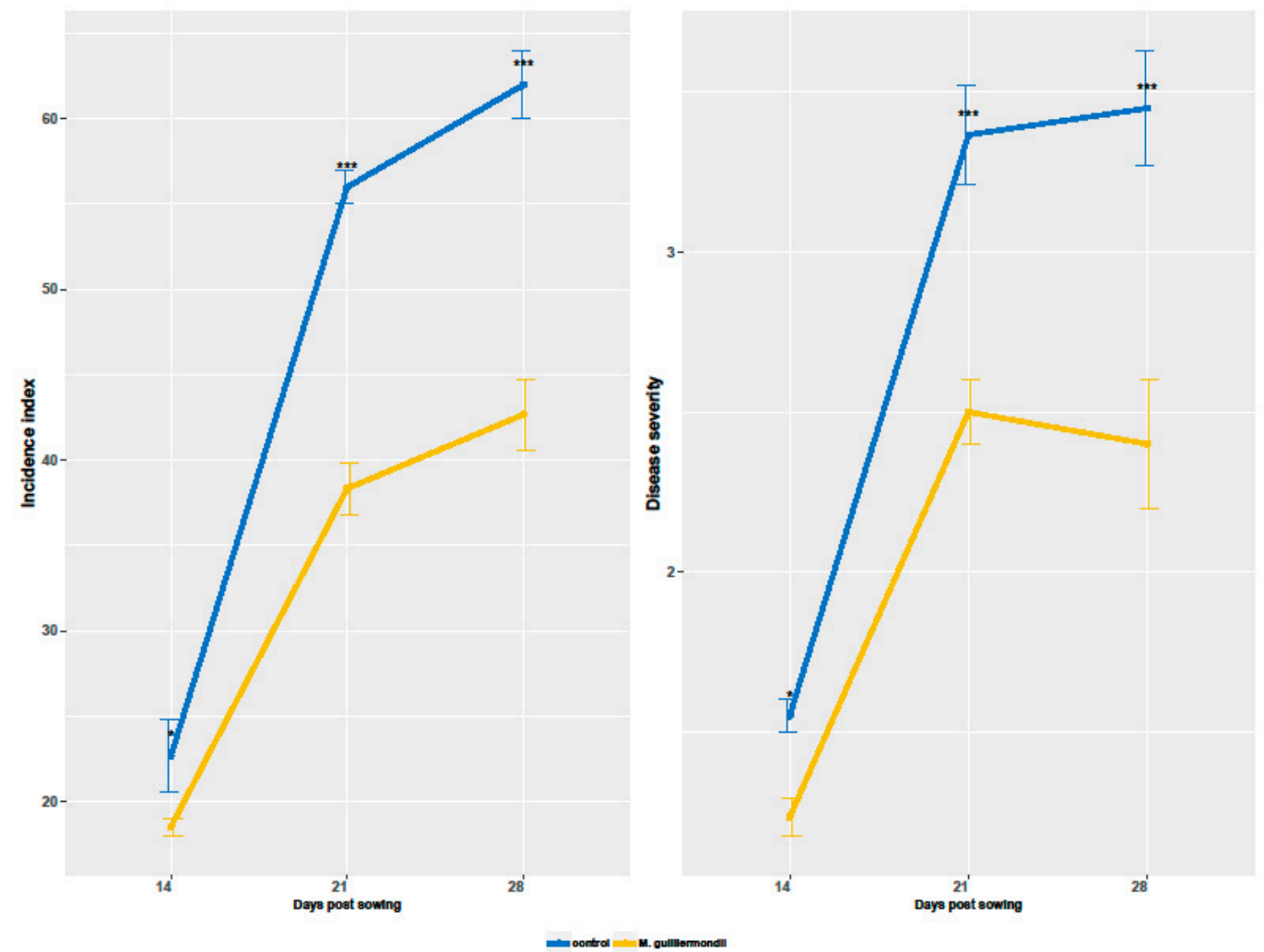

Figure 1. The effect of seed coating with M. guilliermondii on the evolution of Fusarium crown rot incidence and severity, at 14, 21 and 28 das. Data presented are the mean values \pm standard deviation. The symbols of statistical significance are shown; ns: non-significant, ${ }^{*}: p<0.05 ;{ }^{* *}: p<0.01$; ***: $p<0.001$.

2.3. Effect of Seed Coating with M. guilliermondii and Infection with F. culmorum on the Change in Leaf Pigments

The two-way ANOVA showed that contents of chlorophyll, flavonoids and anthocyanins and NBI of leaves were significantly affected by the coating treatment, the infection, and their interaction (Table 2). The one-way ANOVA showed that the treatments significantly affected chlorophyll, flavonols, anthocyanins, and NBI at almost all the time points (Figure 2). 
Table 2. Two-way ANOVA of chlorophyll, flavonols, anthocyanins, and the nitrogen balance index (NBI) contents.

\begin{tabular}{ccccc}
\hline & Chlorophyll $\left(\mu \mathrm{g} / \mathrm{cm}^{2}\right)$ & Flavonols (R.U) & $\begin{array}{c}\text { Anthocyanins } \\
\text { (R.U) }\end{array}$ & NBI (mg/g) \\
\hline Coating(C) & $53.5^{* * *}$ & $0.090^{* * *}$ & $0.0201^{* * *}$ & $348.6^{* * *}$ \\
Infection (I) & $339.6^{* * *}$ & $0.093^{* * *}$ & $0.0018^{*}$ & $894.1^{* * *}$ \\
$\mathrm{C} \times \mathrm{I}$ & $102.0^{* * *}$ & $0.018^{*}$ & $0.0427^{* * *}$ & $175.7^{* * *}$ \\
\hline
\end{tabular}

The sum square values with statistical significance are shown (ns: non-significant, ${ }^{*}: p<0.05 ; * *: p<0.01$; $* * *: p<0.001)$.
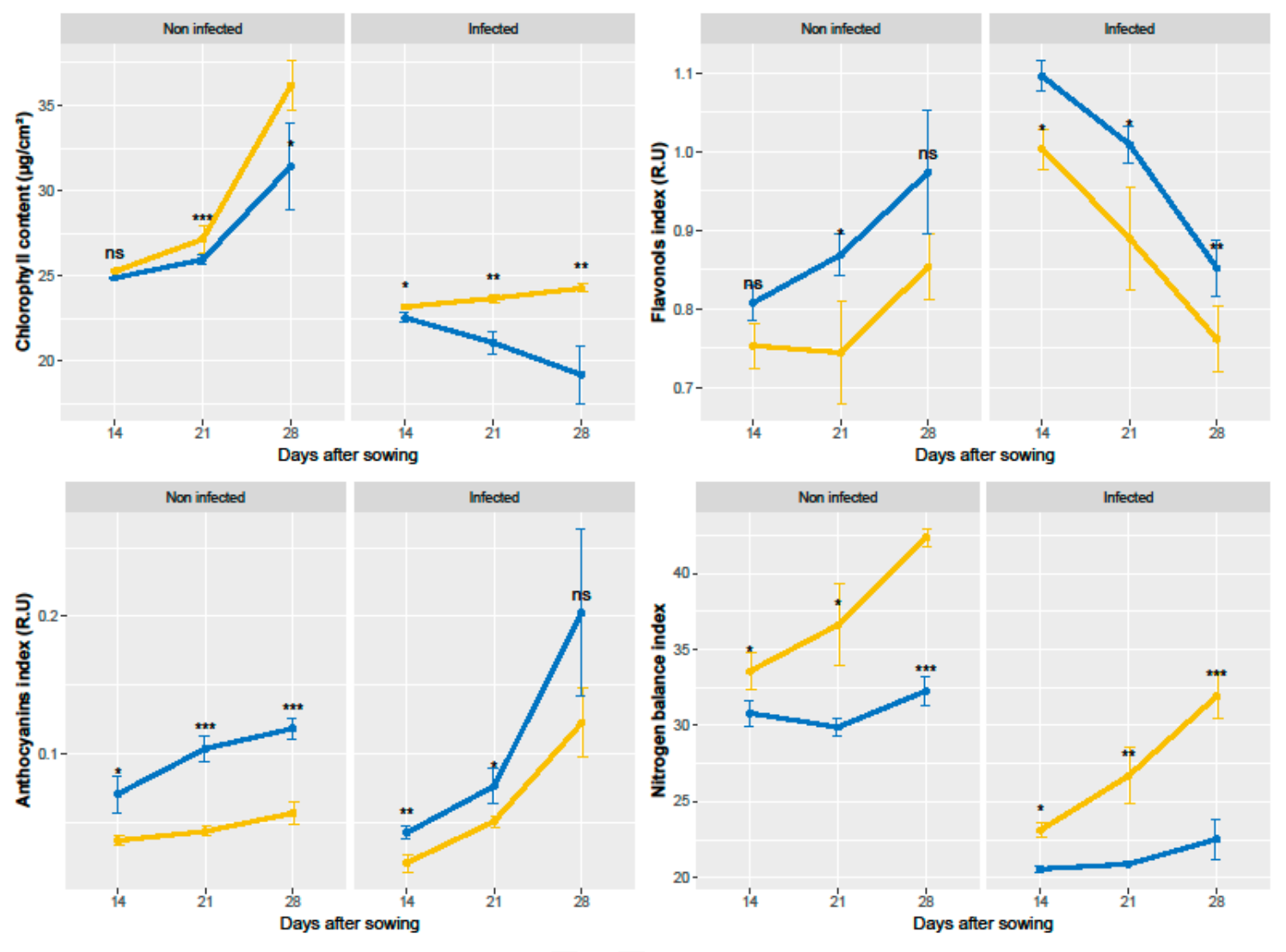

Figure 2. The effect of seed coating with M. guilliermondii on the kinetics of chlorophyll, flavonoids, anthocyanins, and nitrogen balance index in wheat leaves, under non-infected and infected conditions by F. culmoum. Data presented are the mean values with standard deviation. The symbols of statistical significance are shown; ns: non-significant, ${ }^{*}: p<0.05$; ${ }^{* *}: p<0.01 ;{ }^{* * *}: p<0.001$.

In non-infected conditions, the coating of seeds resulted in higher chlorophyll content and NBI, compared to control, which was more remarkable at 28 das (Figure 2). Additionally, the coating of seeds resulted in a lower content of flavonols and anthocyanins, compared to control. Under infected conditions, control plants witnessed a continuous decrease in chlorophyll and flavonols, associated with a continuous increase of anthocyanins, and a low NBI, compared to non-infected control. Whereas, in the plants derived from infected seeds treated with M. guilliermondii, a continuous increase and a higher level of the chlorophyll content, compared to the infected control, was observed, remarkably at 28 das (IR $=20.9 \%$ ). In addition, compared to the infected control, the seed coating treatment resulted in lower contents of flavonols (DR $=8.4 \%)$ and anthocyanins $(\mathrm{DR}=39.6 \%)$ and a higher NBI (IR $=27.67 \%)$ in leaves. 
2.4. Effect of Seed Coating with M. guilliermondii and Infection with F. culmorum on the Leaf Gas Exchange, Photosynthesis, Stomatal Conductance $(\mathrm{Sc})$, and ABA Content

At 28 das, the results showed that both the coating and infection significantly affected the photosynthesis rate, the stomatal conductance, the transpiration rate, the electron transport rate, and the non-photochemical quenching. However, only the infection significantly affected the intercellular to atmospheric $\mathrm{CO}_{2}$ concentration ratio $(\mathrm{Ci} / \mathrm{Ca})$ and the quantum efficiency of Photosystem II. Moreover, the ABA content was only significantly affected by the coating treatment (Table 3 ). In addition, only the $\mathrm{Ci} / \mathrm{Ca}$ ratio was significantly affected by the interaction coating $\mathrm{x}$ infection $(\mathrm{C} \times \mathrm{I})$.

Under non-infected conditions, the seed coating by $M$. guilliermondii enhanced the photosynthesis rate, the stomatal conductance, the internal $\mathrm{CO}_{2}$ concentration, the electron transport rate, the transpiration rate, and decreased the non-photochemical quenching and the ABA content, with no significant impact on the quantum efficiency of photosystem II (Table 3). In control plants, the infection with F. culmorum resulted in the reduction of the photosynthesis rate $(\mathrm{DR}=48.6 \%)$, the stomatal conductance $(\mathrm{DR}=69.9 \%)$, the $\mathrm{Ci} / \mathrm{Ca}$ intercellular to atmospheric ratio ( $\mathrm{DR}=8.45 \%$ ), the quantum efficiency of Photosystem II $(\mathrm{DR}=29.75 \%)$, the electron transport rate $(\mathrm{DR}=25.15 \%)$, and the transpiration rate $(\mathrm{DR}=53.03 \%)$. The impact of the infection in control plants was also characterized by an increase of the non-photochemical quenching (IR $=13.48 \%$ ), and ABA content (IR $=25.11 \%$ ). Under infected conditions, the seed coating with M. guilliermondii resulted in a lower reduction of the photosynthesis rate $(\mathrm{DR}=30.99 \%)$, the stomatal conductance $(\mathrm{DR}=42 \%)$, the quantum efficiency of Photosystem II (DR $=17.47 \%)$, the electron transport rate $(\mathrm{DR}=5.49 \%)$, and a higher transpiration rate $\left(3.41 \mathrm{mmol} \mathrm{H}_{2} \mathrm{O} \mathrm{m}^{-2} \mathrm{~s}^{-1}\right)$ (Tables 3 and 4). Jointly, it resulted in a lower increase of the non-photochemical quenching $(\mathrm{IR}=9.20 \%)$, and a lower ABA content $(0.181 \mathrm{ng} / \mathrm{g} \mathrm{FW})$. Unlike the plant control, the seed coating with $M$. guilliermondii increased the internal $\mathrm{CO}_{2}$ concentration $(\mathrm{IR}=51.34 \%$ ).

\subsection{The Interrelationship among the Physiological Traits and the Disease Severity and Incidence}

The correlation matrix (Figure 3) denotes that the traits that have significant positive correlations $(p=0.001)$ have been divided into two clusters based on the results of hierarchical clustering; cluster 1 include the disease severity, the anthocyanins and flavonoids contents and the non-photochemical quenching $(\mathrm{r}=0.71-0.86)$, the second cluster includes the germination rate, the shoot length, the transpiration rate, chlorophyll content, the NBI index, the photosynthesis rate, the stomatal conductance, the plant biomass, phi2, ETR, the quantum efficiency of Photosystem II, and the photosynthetic electron transport $(\mathrm{r}=0.19-0.97)$. In addition, all of the traits belonging to cluster 1 (disease severity, anthocyanins, flavonoids and the non-photochemical quenching) were negatively correlated to all of the traits belonging to cluster 2 (germination rate, shoot length, transpiration rate, chlorophyll, NBI, photosynthesis rate, stomatal conductance, plant biomass, phi2, ETR, quantum efficiency of Photosystem II, photosynthetic electron transport). The root length was positively correlated to ABA and negatively correlated to the intercellular to atmospheric $\mathrm{CO}_{2}(\mathrm{Ci} / \mathrm{Ca})$. According to the correlation analyses, all the measured plant traits have been selected as potentially useful traits for investigating the implication of seed coating treatment in disease resistance of wheat plants. 


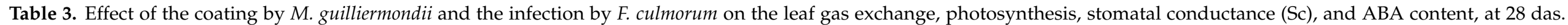

Values are means \pm SD of three replicates.

\begin{tabular}{|c|c|c|c|c|c|c|c|c|c|c|c|c|c|c|c|c|c|}
\hline \multirow{2}{*}{\multicolumn{2}{|c|}{ Traits }} & \multirow{2}{*}{\multicolumn{2}{|c|}{ 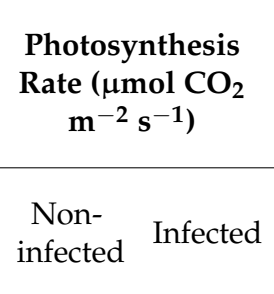 }} & \multirow{2}{*}{\multicolumn{2}{|c|}{$\begin{array}{l}\begin{array}{c}\text { Stomatal Con- } \\
\text { ductance (mol }\end{array} \\
\left.\mathbf{H}_{2} \mathbf{O ~ m}^{-2} \mathrm{~s}^{-1}\right) \\
\begin{array}{c}\text { Non- } \\
\text { infected }\end{array}\end{array}$}} & \multicolumn{2}{|c|}{$\begin{array}{c}\text { Intercellular to } \\
\text { Atmospheric } \mathrm{CO}_{2} \\
\text { Concentration } \\
\mathrm{Ci} / \mathrm{Ca}\end{array}$} & \multicolumn{2}{|c|}{$\begin{array}{c}\text { Quantum } \\
\text { Efficiency of } \\
\text { Photosystem II } \\
\text { (фPSII) }\end{array}$} & \multicolumn{2}{|c|}{ 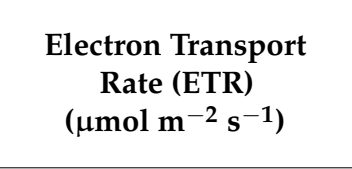 } & \multicolumn{2}{|c|}{$\begin{array}{c}\text { Transpiration } \\
\text { Rate (mmol } \\
\left.\mathrm{H}_{2} \mathrm{O} \mathrm{m}^{-2} \mathrm{~s}^{-1}\right)\end{array}$} & \multicolumn{2}{|c|}{$\begin{array}{l}\text { Non-Photochemical } \\
\text { Quenching (qN) }\end{array}$} & \multicolumn{2}{|c|}{ ABA (ng/g FW) } \\
\hline & & & & & & $\begin{array}{c}\text { Non- } \\
\text { Infected }\end{array}$ & Infected & $\begin{array}{l}\text { Non- } \\
\text { In- } \\
\text { fected }\end{array}$ & Infected & $\begin{array}{c}\text { Non- } \\
\text { Infected }\end{array}$ & Infected & $\begin{array}{l}\text { Non- } \\
\text { infected }\end{array}$ & Infected & $\begin{array}{l}\text { Non- } \\
\text { infected }\end{array}$ & Infected & $\begin{array}{l}\text { Non- } \\
\text { infected }\end{array}$ & Infected \\
\hline \multicolumn{2}{|c|}{ Control } & $\begin{array}{c}18.30^{\mathrm{b}} \pm \\
3.20\end{array}$ & $\begin{array}{l}9.40^{\mathrm{c}} \pm \\
0.25\end{array}$ & $\begin{array}{l}0.399^{b} \pm \\
0.01\end{array}$ & $\begin{array}{c}0.12^{\mathrm{c}} \pm \\
0.01\end{array}$ & $\begin{array}{c}287.66^{\mathrm{ab}} \pm \\
48.78\end{array}$ & $\begin{array}{l}=263.33^{b} \pm \\
32.39\end{array}$ & $\begin{array}{c}=0.205^{\mathrm{a}} \pm \\
0.014\end{array}$ & $\begin{array}{c}0.144^{\mathrm{b}} \pm \\
0.018\end{array}$ & $\begin{array}{c}125722.5^{\mathrm{b}} \\
733\end{array}$ & $\begin{array}{c} \pm 94096.5^{c} \pm \\
12567\end{array}$ & $\begin{array}{c}4.94^{\mathrm{b}} \pm \\
0.99\end{array}$ & $\begin{array}{c}2.32^{\mathrm{c}} \pm \\
0.53\end{array}$ & $\begin{array}{l}1835.33^{\mathrm{bc}} \pm \\
78.38\end{array}$ & $\begin{aligned}= & 2121.33^{\mathrm{a}} \pm \\
& 103.63\end{aligned}$ & $\begin{array}{c}0.826^{\mathrm{a}} \pm \\
0.033\end{array}$ & $\begin{array}{c}1.103^{\mathrm{a}} \pm \\
0.368\end{array}$ \\
\hline \multicolumn{2}{|c|}{ M. guilliermondii } & $\begin{array}{c}25.26^{\mathrm{a}} \pm \\
5.10\end{array}$ & $\begin{array}{c}17.43^{\mathrm{b}} \pm \\
0.73\end{array}$ & $\begin{array}{c}0.66^{\mathrm{a}} \pm \\
0.24\end{array}$ & $\begin{array}{l}0.24^{\mathrm{bc}} \pm \\
0.08\end{array}$ & $\begin{array}{c}334.33^{\mathrm{a}} \pm \\
6.65\end{array}$ & $\begin{array}{c}162.66^{\mathrm{c}} \pm \\
50.95\end{array}$ & $\begin{array}{l}0.206^{\mathrm{a}} \pm \\
0.019\end{array}$ & $\begin{array}{c}0.170^{\mathrm{b}} \pm \\
0.005\end{array}$ & $\begin{array}{c}145665.0^{\mathrm{a}}= \\
3059\end{array}$ & $\begin{array}{c} \pm 137664.5^{\mathrm{ab}} \\
5484\end{array}$ & $\begin{array}{c} \pm 7.44^{\mathrm{a}} \pm \\
0.96\end{array}$ & $\begin{array}{c}3.41^{\mathrm{c}} \pm \\
0.39\end{array}$ & $\begin{array}{c}1729.33^{c} \pm \\
37.58\end{array}$ & $\begin{array}{c}1904.66^{\mathrm{b}} \pm \\
80.16^{\mathrm{N}}\end{array}$ & $\begin{array}{c}0.105^{\mathrm{b}} \pm \\
0.000\end{array}$ & $\begin{array}{c}0.181^{\mathrm{b}} \pm \\
0.005\end{array}$ \\
\hline \multirow{3}{*}{ ANOVA } & $\begin{array}{l}\text { Coating } \\
\text { (C) }\end{array}$ & \multicolumn{2}{|c|}{$168.75^{* *}$} & \multicolumn{2}{|c|}{0.1114 * } & \multicolumn{2}{|c|}{$1519 \mathrm{~ns}$} & \multicolumn{2}{|c|}{$0.000520 \mathrm{~ns}$} & \multicolumn{2}{|c|}{$3.025 \mathrm{e}+09^{* * *}$} & \multicolumn{2}{|c|}{$9.67^{* *}$} & \multicolumn{2}{|c|}{$78085 * *$} & \multicolumn{2}{|c|}{$2.0240^{* * *}$} \\
\hline & $\begin{array}{l}\text { Infection } \\
\text { (I) }\end{array}$ & \multicolumn{2}{|c|}{$210.00^{* *}$} & \multicolumn{2}{|c|}{$0.3626^{* *}$} & \multicolumn{2}{|c|}{$31519^{* *}$} & \multicolumn{2}{|c|}{$0.006960^{* * *}$} & \multicolumn{2}{|c|}{$1.178 \mathrm{e}+09 * *$} & \multicolumn{2}{|c|}{$33.17^{* * *}$} & \multicolumn{2}{|c|}{$159621^{* * *}$} & \multicolumn{2}{|c|}{$0.0938 \mathrm{~ns}$} \\
\hline & $C \times I$ & \multicolumn{2}{|c|}{$0.85 \mathrm{~ns}$} & \multicolumn{2}{|c|}{$0.0169 \mathrm{~ns}$} & \multicolumn{2}{|c|}{$18330^{* *}$} & \multicolumn{2}{|c|}{$0.000469 \mathrm{~ns}$} & \multicolumn{2}{|c|}{$4.186 \mathrm{e}+08^{*}$} & \multicolumn{2}{|c|}{$1.52 \mathrm{~ns}$} & \multicolumn{2}{|c|}{$9185 \mathrm{~ns}$} & \multicolumn{2}{|c|}{$0.0301 \mathrm{~ns}$} \\
\hline
\end{tabular}

Values with different letter are significantly different at $p=0.05$.

Table 4. The decrease and the increase rate of the leaf gas exchange, photosynthesis, stomatal conductance (Sc), and ABA content at 28 das.

\begin{tabular}{|c|c|c|c|c|c|c|c|c|}
\hline \multirow[b]{2}{*}{ Traits } & \multicolumn{6}{|c|}{ Decrease Rate (\%) } & \multicolumn{2}{|c|}{ Increase Rate (\%) } \\
\hline & $\begin{array}{l}\text { Photosynthesis rate } \\
\left(\mu \mathrm{mol} \mathrm{CO} \mathrm{m}^{-2} \mathrm{~s}^{-1}\right)\end{array}$ & $\begin{array}{c}\text { Stomatal } \\
\text { conductance } \\
\left(\mathrm{mol} \mathrm{H}_{2} \mathrm{O} \mathrm{m}^{-2} \mathrm{~s}^{-1}\right)\end{array}$ & $\begin{array}{c}\text { Intercellular to } \\
\text { atmospheric } \mathrm{CO}_{2} \\
\text { concentration } \mathrm{Ci} / \mathrm{Ca}\end{array}$ & $\begin{array}{c}\text { Quantum efficiency } \\
\text { of Photosystem II } \\
(\phi P S I I)\end{array}$ & $\begin{array}{l}\text { Electron transport } \\
\text { rate }(\text { ETR }) \\
\left(\mu \mathrm{mol} \mathrm{m}{ }^{-2} \mathrm{~s}^{-1}\right)\end{array}$ & $\begin{array}{l}\text { Transpiration rate } \\
\left(\mathrm{mmol} \mathrm{H}_{2} \mathrm{O} \mathrm{m}^{-2} \mathrm{~s}^{-1}\right)\end{array}$ & $\begin{array}{l}\text { Non-photochemical } \\
\text { quenching (qN) }\end{array}$ & $\begin{array}{c}\text { ABA } \\
(\mathrm{ng} / \mathrm{g} F W)\end{array}$ \\
\hline Control & 48.63 & 69.92 & 8.45 & 29.75 & 25.15 & 53.03 & 13.48 & 25.11 \\
\hline M. guilliermondii & 30.99 & 42 & 51.34 & 17.47 & 5.49 & 54.16 & 9.20 & 41.98 \\
\hline
\end{tabular}




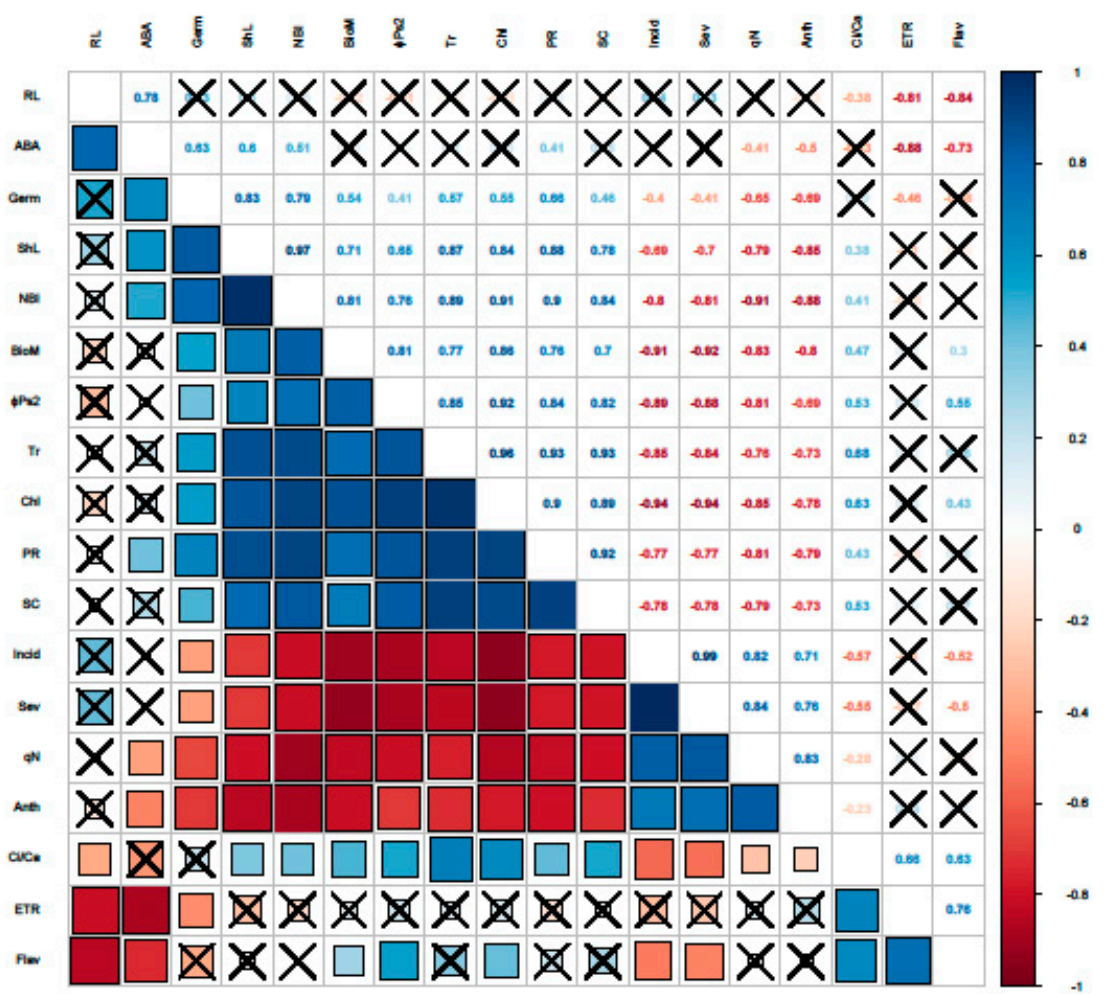

Figure 3. Pearson's correlation matrix among physiological traits and disease incidence and severity. The darker, bigger blue and red squares (lower left diagonal) indicate stronger positive and negative correlations, respectively. Crossed cells indicate statistically insignificant correlations. Pearson's coefficients ( $\mathrm{r}$ ) of correlation are shown (upper right diagonal). Abbreviations of metabolites are for Incid: incidence, Sev: severity, Anth: anthocyanins, qN: non photochemical quenching, Flav: flavonols, RL: roots length, ABA: ABA content, $\mathrm{Ci} / \mathrm{Ca}$ : intercellular versus atmospheric $\mathrm{CO}_{2}$ concentration, Germ: germination, ShL: shoot lengths, Tr: transpiration rate, Chl: chlorophyll, NBI: nitrogen balance index, PR: photosynthesis rate, SC: stomatal conductance, BioM: Biomass, $\phi$ PSII: quantum efficiency of Photosystem II, ETR: photosynthetic electron transport.

\section{Discussion}

\subsection{Effect of M. guilliermondii on Physiological Traits Under Non-Infected Conditions}

Seed coating with beneficial microorganisms has been proposed as a very effective approach to promote durum wheat yield [8]. Previous studies demonstrated that treatment with $M$. guilliermondii improves maize (Zea mays L.) productivity and reduces the needs for chemical fertilization [20]. Besides, a combined treatment based on M. guilliermondii and a chemical fertilizer was found to promote tomato plant growth under control conditions [21]. Furthermore, recent studies showed that the strain M. guilliermondii Mg-11, isolated from Spanish vineyards, promoted Maize seedling development [22]. The observed positive effects of M. guilliermondii on seed germination and plant growth could be attributed to seed biopriming; the seed biopriming triggers the release and the production of phytohormones and enzymes which are involved in seed germination and plant growth ([23] Mahmood et al., 2016; [24] Bennett et al., 1998). Further, the growthpromoting potential of Meyerozyma spp. may also be accrued owing to its ability to induce IAA (indole-3-acetic acid) production [20]. The IAA hormone performs many regulatory functions, including stimulating plant cell enlargement, differentiation of xylem and phloem, cambium cell division, root initiation and lateral root formation [25].

Phytohormones play important roles in regulating development processes and signalling networks elaborated in plant responses to biotic and abiotic stresses [26]. Since ABA is frequently known as a stress hormone [27], the lower content of ABA in M. guilliermondii -treated plants, under both non-infected and infected conditions, denotes the healthy status 
of plants and the lower subjection to stressful conditions. This finding was in line with that of [15] who have observed a decrease in the ABA contents in plants of Maize inoculated with M. caribbica.

This study showed that in non-infected conditions, M. guilliermondii enhanced various photosynthetic attributes; namely chlorophyll content, NBI, the photosynthesis rate, the stomatal conductance, the $\mathrm{Ci} / \mathrm{Ca}$ ratio, the electron transport rate, the transpiration rate, and resulted in a lower accumulation of flavonols and anthocyanins together with a lower non-photochemical quenching. Indeed, secondary metabolites including phenolic acids and flavonoids are necessary molecules for plant metabolism and growth, whereas the wide variety and high diversity of secondary products are key components for plants to interact with the environment in the adaptation to both biotic and abiotic stress condition [28]. The use of biostimulants has shown positive effects on plant growth [29], improving root hair and the $\mathrm{N}$ uptake, leading to increased net photosynthesis, transpiration rate, and the $\mathrm{Ci} / \mathrm{Ca}$ ratio in maize [30].

\subsection{Effect of the Infection with F. culmorum on the Physiological Traits in Control Plants}

Despite the several existing studies on the disease development caused by F. culmorum, F. graminearum and F. pseudograminearum and the related host-pathogen interactions, very little is known about the impact of seed infection with F. culmorum on photosynthesis and the early host responses at the seedling stage [31]. Our study may contribute to improve the understanding of the impact of seed infection with F. culmorum on seedling stand, stomatal behaviour, and photosynthesis-related traits. As we observed in this study, the infection of seeds with F. culmorum induced a loss of seed germination resulting in a less dense plant stand. Moreover, the seedlings that managed to germinate from infected seeds had a reduced seedling growth. The infection effects are a consequence of pathogen dynamics; F. culmorum can effectively penetrate seedling roots, migrate from hypocotyl to the upper stem internodes and leaves, colonize the host's tissue and cells, block the vascular bundles, and disturb nutritional supply, and metabolic processes [32,33], leading to a significant decrease in seedling growth. In our study, the infection effects were reflected in the observed continuous reduction of chlorophyll content which has been reported to result from either the destruction of chloroplasts and the gradual decomposition of chlorophyll in fungus affected cells [32], or from immobilization of nutrients required for chlorophyll formation and photosynthesis [34].

At the beginning of the disease process, plants induced flavonols as metabolites involved in the antioxidative reaction and defence response of plants [35]. However, along with the increasing severity and incidence of the disease, plants were no longer able to produce the antioxidant flavonols. As a result, the anthocyanins continued to rise which are involved in the reduction of photo-oxidative damage [36]. This resulted in the reduction of the NBI, which indicates that the plant directs its metabolism towards an increased production of flavonols (carbon-based secondary compounds), rather than towards its primary metabolism of protein synthesis (nitrogen-containing molecules) [37]. The latter state indicates the allocation of resources for the onset of defense reactions and biosynthesis of protective compounds rather than towards the process of photosynthesis, leading to a down-regulated photosynthesis [38].

The observed disturbed photosynthetic activity agrees with the findings of [39] who showed that the damage in the photosynthetic system occurred when the integrity of the host plant's cellular structures was destroyed by fungal hyphae. [40] have mentioned that the mycotoxins produced by the fungi may also contribute to a strong reduction or even to the total loss of photosynthetic activity. The decrease in the photochemistry was associated with accumulation of ABA, stomatal closure and the related reduction of carbon content and transpiration. It can be suggested that the latter events could underline the disturbed water transport caused by the aptitude of the pathogen to colonize the root cortex and the vascular system [31]. The stomatal closure is an important factor contributing to low $\mathrm{CO}_{2}$ 
uptake and transportation of non-structural carbon which is an important component of photosynthesis leading to $\mathrm{C}$ starvation which further affects other processes [41].

\subsection{Effect of M. guilliermondii on the Physiological Traits Following to Fusarium-Infection}

Seed coating with M. guilliermondii lowered the damaging effect of F. culmorum on germination, and this is most likely owing to a repressed mycelium growth of $F$. culmorum on the surface of seeds. Following to the Fusarium-infection, the plants emerging from M. guilliermondii-coated seeds were able to reduce the development of wilt symptoms and to suppress the pathogen growth. These yeast species were characterized as active biological agents in several studies against fungal pathogens, including cabbage black leaf and tomato bacterial wilt disease [20], citrus blue mold [18], Colletotrichum capsici [42], and Rhizopus stolonifer in postharvest tomatoes [43]. Our research led the way to a possible antagonist potential of M. guilliermondii and competition for space and nutrients.

Moreover, our study clearly shows that applications of M. guilliermondii isolates could reduce pathogen damage and also promote durum wheat growth, leading to an increase in the shoots, roots length and the biomass compared to the control. This may be owing to the phytohormone produced by the yeast under stress conditions such as IAA and which involved in the plant growth. To face pathogens, many mechanisms activated by the yeast include the production of cell wall lytic enzymes and toxic volatile compounds [20], together with IAA production. In addition, some isolates are also known for their ability to induce systemic resistance against different pathogens. For example [18] reported that tomato fruits inoculated with Pichia (Meyerozyma, anamorph) guilliermondii activate defensive enzymes such as peroxidase polyphenoloxidase, superoxide dismutase, catalase, phenylalanine ammonia-lyase, chitinase and -1,3-glucanase activities [44].

Following the Fusarium-infection, the application of the bio-agent M. guilliermondii demonstrated an effective restoration of physiological traits and photosynthetic pigments compared to non-inoculated control of wheat plants, especially the increase of the photosynthesis rate. Moreover, the effect of M. guilliermondii on the leaf pigments of infected plants, causing a decrease in the contents of flavonoids and anthocyanins, together with an increase in the chlorophyll content, is only an illustration of the lower subjection of plants to stress and to the related oxidative damage. These results are in agreement with the finding of [15], where the inoculation of maize plants with $M$. caribbica promoted the chlorophyll contents under stress conditions.

In addition of the secondary metabolites, in plant-pathogen interactions, hormones modulate a series of defence responses, which limit pathogen spread [45]. In the present study, a decrease of synthesis of ABA was observed under F. culmorum infection in plants treated with M. guilliermondii compared the control. This finding was in agreement with the results of [15], who reported that Maize plant treated by $M$. caribbica showed lower endogenous ABA. Moreover, in Arabidopsis, ABA has been shown to antagonize the jasmonic acid signalling pathway, and this antagonism is considered responsible for the induction of disease susceptibility by ABA against the soilborne fungus F. oxysporum [46]. The observed potential of M. guilliermondii in growth promotion and disease control in seedlings might be achieved through the phenomenon so called bio-priming of seeds. In this context, [47] have reported that the colonization of seedling roots with biopriming microorganisms induces a broad-spectrum of resistance mechanisms in plants, reduces the root rot diseases caused by soil-borne plant pathogens.

\section{Materials and Methods}

\subsection{Yeast and Pathogen Material}

M. guilliermondii, a yeast strain INAT (MT731365) was collected from tomato stem isolated and characterized in the National Institute of Agronomy of Tunis, Tunisia. A pure culture was maintained at $4{ }^{\circ} \mathrm{C}$ on potato dextrose agar agar plates filled with $15 \mathrm{~mL}$ (PDA: extract of boiled potatoes, $200 \mathrm{~mL}$ dextrose, $20 \mathrm{~g}$ agar and distilled water, $800 \mathrm{~mL}$ ). The active yeast cells were prepared in $250 \mathrm{~mL}$ flaks containing $50 \mathrm{~mL}$ of nutrient yeast 
dextrose (PDL, PDA without agar) with a loop yeast inoculum and incubated on rotary shaker at a speed of $180 \mathrm{rpm}$ for $48 \mathrm{~h}$ at $28^{\circ} \mathrm{C}$. After centrifugation $\left(5000 \mathrm{rpm}, 4{ }^{\circ} \mathrm{C}, 5 \mathrm{~min}\right)$, the cells were collected and washed with distilled water. Then, the yeast cell concentration is adjusted to 108 cells $\mathrm{m}^{-1}$.

The fungal pathogen F. culmorum (FC) was isolated from brown lesions in wheat roots sampled from severely infected fields of north Tunisia, kindly provided by Dr. Samia Gargouri (National Institute of Agronomic Research of Tunisia). The pathogen inoculum used for plant inoculation were prepared as previously described by [11]. The fungal pathogen was maintained on PDA and was grown 7 days at $28^{\circ} \mathrm{C}$. Fungal macroconidia was produced in barley seeds. The seeds were inoculated by Fusarium strains and kept for 2 weeks at $25^{\circ} \mathrm{C}$ in the dark. Conidial suspensions were diluted with autoclaved water to a final concentration of $1 \times 106$ conidia $\mathrm{mL}^{-1}$ containing $0.05 \%(v / v)$ Tween 20 .

\subsection{Seed Coating and Infection with F. culmorum}

Seeds of durum wheat (Triticum turgidum subsp.durum.) cv. Karim, a sensitive soilborne fungal pathogen variety, were used. Prior to use, seeds were surface sterilized; soaked for $2 \mathrm{~min}$ in an aqueous solution of $0.6 \%$ sodium hypochlorite $(\mathrm{NaOCl})$, then for $2 \mathrm{~min}$ in $70 \%$ ethanol, and finally rinsed three times with sterile distilled water. The surfacesterilized seeds were subjected firstly to the infection with F. culmorum, and subsequently to the seed coating treatment with M. guilliermondii. In details, surface-sterilized seeds were soaked in the conidial suspension of F. culmorum or in sterile distilled water containing $0.05 \%$ Tween 20 as the non-infected control. The soaking seeds were kept for $16 \mathrm{~h}$ in the dark at $25{ }^{\circ} \mathrm{C}$ [8]. Afterwards, both infected and non-infected seeds were coated with M. guilliermondii filtrate as described by [8]. The coating product Agicote Rouge T17 (AEGILOPS Applications, France) was used, playing the role of the adhesion product, containing propane-1,2-diol (5-10\%), polyethylene glycol mono (tristyrylphenyl) ether (5-10\%), and 1,2-benzisothiasol 3(2H)-one (0.0357).

\subsection{Wheat Growth and Experimental Conditions}

All the experiments were conducted from October to mid December 2018 in the experimental facilities of the Faculty of Biology at the University of Barcelona (Spain). Wheat plants were grown in pots of $16 \mathrm{~cm}$ diameter containing a mixture of standard substrate: perlite $(1: 1 ; v / v)$ in an environmentally controlled growth chamber (Conviron E15; Controlled Environments, Winnipeg, MB, Canada). Pots were maintained under controlled conditions of temperature $\left(22 \pm 3^{\circ} \mathrm{C}\right)$, relative humidity $(40-50 \%)$, and a photoperiod of 16:8 h (light:darkness). Four seeds were planted per pot. The plants were uniformly irrigated every 2 days with $50 \%$ Hoagland's nutrient solution (Hoagland and Arnon, 1950). A Complete Randomized Design (CRD) with four combinations of seeds and three replicates was adopted (Figure 4). The four combinations of sown seeds consisted of: (i) non-infected and coated with M. guilliermondii, (ii) infected and coated with M. guilliermondii (iii) non-infected and non-coated control, and (iv) infected and non-coated control. Pots were rotated three times a week to ensure uniform growth conditions.

\subsection{Measurements}

The measurements were taken at different time points; at 7, 14, 21, 28, and 40 days after sowing (das) (Figure 4). They include measurements on the fully expanded leaf: Leaf gas exchange, leaf pigment content, seed germination, disease assessment, plant-growth traits, ABA analysis. Details are provided below (Figure 4). 


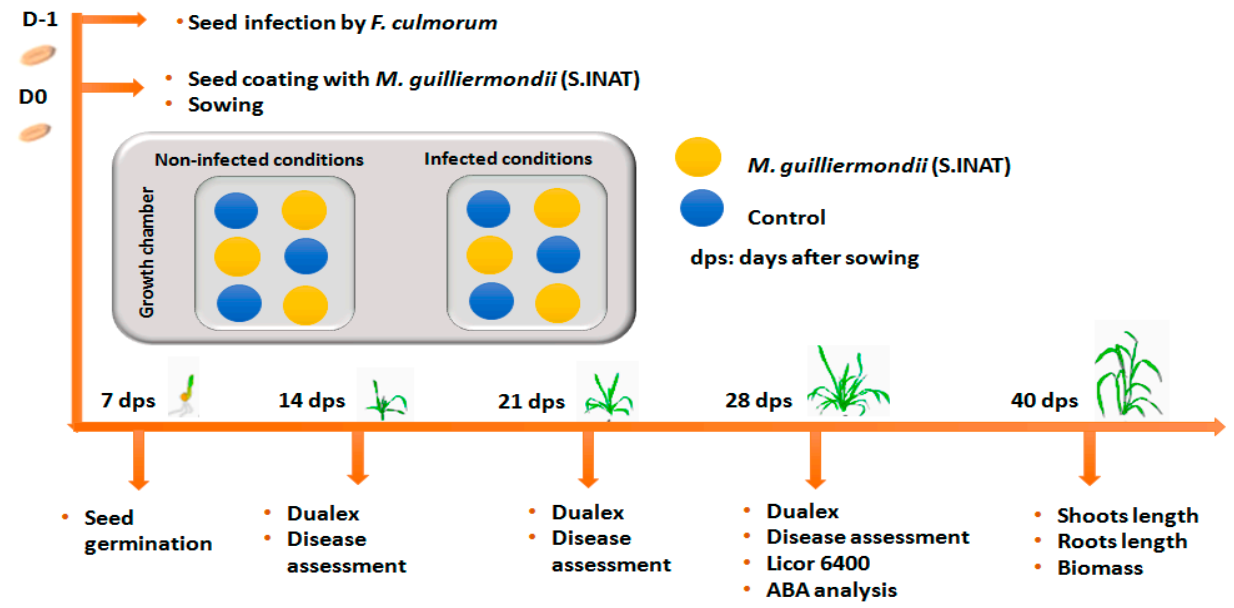

Figure 4. Schematic illustration of the experimental design.

\subsection{Fusarium Crown Rot Disease Assessment}

At 14, 21 and 28 das, three plants per treatment were sampled to measure the evolution of disease incidence and severity, according to the symptoms caused by the endophytic pathogen F. culmorum in wheat plants. The incidence index of the disease was recorded as the percentage of plants showing browning symptoms on stem base. The evaluation of the disease severity of FCR was scored in the seedling stage and rated on a $0-5$ scale based on the typical symptoms of browning as previously described by [6].

\subsection{Dualex Sensor Measurements and Pigments Analysis}

At 14, 21, and 28 days, the contents in leaf photosynthetic pigments were measured in the last fully expanded leaves of 3 plants per treatment, using a portable leaf meter (Dualex Scientific+TM, FORCE-A, France) as described by Goulas et al. (2004). This optical sensor allows a non-destructive measurement of chlorophyll (Chl) content in leaves (given in $\mu \mathrm{g} \mathrm{cm}^{-2}$ ), flavonols (Flav) and anthocyanins (Anth) contents in leaves (which are given in relative absorbance units), and the nitrogen balance index (NBI; ratio Chl/Flav).

\subsection{Leaf Gas Exchange}

Leaf gas exchange was measured in the fully expanded leaf at 28 das. Three plants per treatment were assessed using a LI-6400 infrared gas analyzer (LI-6400 Portable photosynthesis system, LI-COR, Lincoln, NE, USA), operating with a 6400-02 LED light source (LICOR) providing $400 \mu \mathrm{mol} \mathrm{m}^{-2} \mathrm{~s}^{-1}$ PPFD. The parameters measured were the rate of photosynthesis $(\mathrm{Pr})\left(\mu \mathrm{mol} \mathrm{CO} \mathrm{m}^{-2} \mathrm{~s}^{-1}\right)$, the rate of transpiration $(\mathrm{Tr})\left(\mathrm{mmol} \mathrm{H}_{2} \mathrm{O} \mathrm{m}^{-2} \mathrm{~s}^{-1}\right)$, the stomatal conductance (SC) $\left(\mathrm{mol} \mathrm{H}_{2} \mathrm{O} \mathrm{m}^{-2} \mathrm{~s}^{-1}\right)$, the intercellular versus the atmospheric concentration of $\mathrm{CO}_{2}(\mathrm{Ci} / \mathrm{Ca})$ and the photosynthetic electron transport rate $(\mathrm{ETR})$ $\left(\mu \mathrm{mol} \mathrm{m} \mathrm{m}^{-2} \mathrm{~s}^{-1}\right)$.

\subsection{ABA Extraction and Quantification}

Abscisic acid (ABA) concentrations were measured at 28 das, by liquid chromatography coupled in tandem with modifications to mass spectrometry (HPLC-MS/MS). Thus, $50 \mathrm{mg}$ samples of the last fully expended leaf were grounded by liquid Nitrogen. To each sample, $500 \mu \mathrm{L}$ of isopropanol/methanol/acetic acid (90:9:1, $v / v / v)$ extraction solvent was added, with $20 \mu \mathrm{L}$ of deuterium-labelled abscisic acid (d6-ABA, 0.5 ppm, Saskatoon, Canada) as the internal standard. The obtained extracts were vortexed and centrifuged at $15,000 \mathrm{rpm}$ at $4^{\circ} \mathrm{C}$ for $4 \mathrm{~min}$; the supernatants were collected, and the pellets were re-extracted with $200 \mu \mathrm{L}$ of the extraction solvent and centrifuged again. Then, supernatants were pooled, dried with Rotavap for $120 \mathrm{~min}$ and reconstituted in $200 \mu \mathrm{L}$ of methanol/water/acetic acid (90:20:0.01, v/v/v) vortexed, centrifuged (10,000 rpm, $10 \mathrm{~min})$, and filtered through a $0.45 \mathrm{~mm}$ PTFE filter (Waters, Milford, MA, USA). Finally, $5 \mathrm{~mL}$ of 
each sample was injected into the LC-MS/MS system. A calibration curve was created using serial dilutions of d6-ABA deuterium labelled internal standard ( $\mu$ g. g-1 FW).

\subsection{Plant-Growth Traits}

At 7 das, the percentage of the germinated seeds in pots was measured. At the end of the experiment ( 40 das), three plants per treatment were sampled for measuring the shoot and root length and plant biomass. For dry weight measurements, roots were washed in tap water until all substrate was removed, then root and shoot samples were dried at $70{ }^{\circ} \mathrm{C}$ for $48 \mathrm{~h}$.

\subsection{Statistical Analyses}

The effects of the coating treatments and infection and their interaction on growth parameters, disease incidence and severity, and physiological parameters were determined through a two-factor (coating $\times$ infection) analysis of variance (ANOVA). The Least significant difference (LSD) test was used to assess differences between the treatments means. The Clustered Pearson correlation matrices were generated using the mean values of physiological and growth traits, which were jointed into most similar clusters according to the cluster function. All statistical analyses as well as figures for time course variation were built with RStudio 1.1.463.

\section{Conclusions}

It might be assumed that M. guilliermondii might have a pivotal function as antagonist and growth promoter. As an antagonist, it repressed the pathogen growth either through competing with it for space and nutrients, or through the release of antifungal compounds, these assumptions surely demand further investigations. In summary, our study provides now evidences, in this case for durum wheat a major crop in the Mediterranean basin, of the seed biopriming with microbial inoculants as a potential alternative to the use of chemical pesticides without any risk to humans, animals or the environment.

Author Contributions: Z.K. and F.C. conducted the green house experiment. M.L.-C., C.L.-C. and M.B.J. conducted hormone analysis and related results' interpretation. Z.K. analysed results and wrote the paper under the supervision of M.B.J., M.L.-C., J.L.A. M.D.S., and W.H. J.L.A. and C.K. reviewed the paper before submission. All authors have read and agreed to the published version of the manuscript.

Funding: This work was financially supported by the Ministry of Research and Higher Education of Tunisia [grant number LR02AGR02], the company Koppert "biological system", Netherlands, and the Spanish Ministry of Economy and Competitiveness (MEC) [grant number AGL2016-76527- R]. J.L.A. acknowledges the support of ICREA Academia, Government of Catalonia, Spain.

Institutional Review Board Statement: Not applicable.

Informed Consent Statement: Not applicable.

Data Availability Statement: Data available in a publicly accessible repository.

Acknowledgments: We thank Harald Mikkelsen and the company Koppert, The Netherlandsand for the support. We thank also the Unitat de Genòmica of the CCiTUB, JosepMatas (Servei de Camps Experimentals, University of Barcelona) for the technical assistance.

Conflicts of Interest: The authors declare no conflict of interest.

\section{References}

1. Fakhfakh, M.M.; Yahyaoui, A.; Rezgui, S.; Elias, E.M.; Daaloul, A. Identification and pathogenicity assessment of Fusarium spp. sampled from durum wheat fields in Tunisia. Afr. J. Biotechnol. 2011, 10, 6529-6539.

2. Chekali, S.; Gargouri, S.; Berraies, S.; Gharbi, M.S.; Nicol, M.J.; Nasraoui, B. Impact of Fusarium foot and root rot on yield of cereals in Tunisia. Tunis. J. Plant Prot. 2013, 8, 75-86.

3. Gargouri, S.; Hajlaoui, M.R.; Guermech, A.; Marrakchi, M. Identification des espèces fongiques associées à la pourriture du pied du blé et étude de leur répartition selon les étages bioclimatiques en Tunisie. EPPO Bull. 2001, 31, 499-503. [CrossRef] 
4. Kammoun, L.G.; Gargouri, S.; Hajlaoui, M.R.; Marrakchi, M. Occurrence and distribution of Microdochium and Fusarium species isolated from durum wheat in northern Tunisia and detection of mycotoxins in naturally infested grain. J. Phytopathol. 2009, 157, 546-551. [CrossRef]

5. Balmas, V.; Scherm, B.; Marcello, A.; Beyer, M.; Hoffmann, L.; Migheli, Q.; Pasquali, M. Fusarium species and chemotypes associated with Fusarium head blight and Fusarium root rot on wheat in Sardinia. Plant Pathol. 2015, 64, 972-979. [CrossRef]

6. Köycü, N.D. Effect on Fusarium culmorum of fungicides used in Wheat seed. In Proceedings of the International Congress on Engineering and Life Science, Kastamonu, Turkey, 26-29 April 2018; Kastamonu University: Kastamonu, Turkey, 2019; pp. 593-601.

7. Wagacha, J.M.; Muthomi, J.W. Fusarium culmorum: Infection process, mechanisms of mycotoxin production and their role in pathogenesis in wheat. Crop Prot. 2007, 26, 877-885. [CrossRef]

8. Ben-Jabeur, M.; Kthiri, Z.; Harbaoui, K.; Belguesmi, K.; Serret, M.D.; Araus, J.L.; Hamada, W. Seed coating with thyme essential oil or Paraburkholderia phytofirmans PsJN strain: Conferring Septoria leaf blotch resistance and promotion of yield and grain isotopic composition in wheat. Agronomy 2019, 9, 586. [CrossRef]

9. Naguib, D.M. Control of Fusarium wilt in wheat seedlings by grain priming with defensin-like protein. Egypt. J. Biol. Pest Control 2018, 28, 68. [CrossRef]

10. Djébali, N. Seed hydropriming effect on Triticum durum and Hordeum vulgare germination, seedling growth and resistance to Fusarium culmorum. Plant Pathol. J. 2012, 11,77-86. [CrossRef]

11. Mnasri, N.; Chennaoui, C.; Gargouri, S.; Mhamdi, R.; Hessini, K.; Elkahoui, S.; Djébali, N. Efficacy of some rhizospheric and endophytic bacteria in vitro and as seed coating for the control of Fusarium culmorum infecting durum wheat in Tunisia. Eur. J. Plant Pathol. 2017, 147, 501-515. [CrossRef]

12. Tyagi, B.; Dubey, A.; Verma, A.; Tiwari, S. Antibacterial activity of phenolics compounds against pathogenic bacteria. Int. J. Pharm. Sci. Rev. Res. 2015, 35, 16-18.

13. Siranidou, E.; Kang, Z.; Buchenauer, H. Studies on symptom development, phenolic compounds and morphological defence responses in wheat cultivars differing in resistance to Fusarium head blight. J. Phytopathol. 2002, 150, 200-208. [CrossRef]

14. Jan, F.G.; Hamayun, M.; Hussain, A.; Iqbal, A.; Jan, G.; Khan, S.A.; Khan, H.; Lee, I.J. A promising growth promoting Meyerozyma caribbica from Solanum xanthocarpum alleviated stress in maize plants. Biosci. Rep. 2019, 39, 10. [CrossRef] [PubMed]

15. Lu, H.-P.; Luo, T.; Fu, H.W.; Wang, L.; Tan, Y.Y.; Huang, J.Z.; Wang, Q.; Ye, G.-Y.; Gatehouse, A.M.R.; Lou, Y.-G.; et al. Resistance of rice to insect pests mediated by suppression of serotonin biosynthesis. Nat. Plants 2018, 4, 338-344. [CrossRef]

16. Baghbani, F.; Lotfi, R.; Moharramnejad, S.; Bandehagh, A.; Roostaei, M.; Rastogi, A.; Kalaji, H.M. Impact of Fusarium verticillioides on chlorophyll fluorescence parameters of two maize lines. Eur. J. Plant Pathol. 2019, 2, 337-346. [CrossRef]

17. Yang, S.; Li, X.; Chen, W.; Liu, T.; Zhong, S.; Ma, L.; Zhang, M.; Zhang, H.; Yu, D.; Luo, P. Wheat resistance to fusarium head blight is associated with changes in photosynthetic parameters. Plant Dis. 2016, 100, 847-852. [CrossRef]

18. Lahlali, R.; Hamadi, Y.; Jijakli, M.H. Efficacy assessment of Pichia guilliermondii strain Z1, a new biocontrol agent, against citrus blue mould in Morocco under the influence of temperature and relative humidity. Biol. Control 2011, 56, 217-224. [CrossRef]

19. Zhao, Y.; Tu, K.; Shao, X.; Jing, W.; Su, Z. Effects of the yeast Pichia guilliermondii against Rhizopus nigricans on tomato fruit. Postharvest Biol. Technol. 2008, 49, 113-120. [CrossRef]

20. Elsharkawy, M.M.; Nakatani, M.; Nishimura, M.; Arakawa, T.; Shimizu, M.; Hyakumachi, M. Suppression of rice blast, cabbage black leaf spot, and tomato bacterial wilt diseases by Meyerozyma guilliermondii TA-2 and the nature of protection. Acta Agric. Scand. Sect. B Soil Plant Sci. 2015, 65, 629-636.

21. Nakayan, P.; Hameed, A.; Singh, S.; Young, L.S.; Hung, M.H.; Young, C.C. Phosphate-solubilizing soil yeast Meyerozyma guilliermondii CC1 improves maize (Zea mays L.) productivity and minimizes requisite chemical fertilization. Plant Soil 2013, 373, 301-315. [CrossRef]

22. Sripontan, Y.; Tan, C.W.; Hung, M.H.; Young, C.C.; Hwang, S.Y. Effects of plant-growth-promoting microorganisms and fertilizers on growth of cabbage and tomato and Spodoptera litura performance. J. Asia Pac. Entomol. 2014, 17, 587-593. [CrossRef]

23. Fernandez-San Millan, A.; Farran, I.; Larraya, L.; Ancin, M.; Arregui, L.M.; Veramendi, J. Plant growth-promoting traits of yeasts isolated from Spanish vineyards: Benefits for seedling development. Microbiol. Res. 2020, 237, 126480. [CrossRef] [PubMed]

24. Mahmood, A.; Turgay, O.C.; Farooq, M.; Hayat, R. Seed biopriming with plant growth promoting rhizobacteria: A review. FEMS Microbiol. Ecol. 2016, 92, 8. [CrossRef] [PubMed]

25. Bennett, M.A. The use of biologicals to enhance vegetable seed quality. Seed Technol. 1998, 20, 198-208.

26. Shih-Yung, H. IAA Production by Streptomyces scabies and Its Role in Plant Microbe Interaction. Ph.D. Thesis, Cornell University, Ithaca, NY, USA, 2010.

27. Qi, P.F.; Balcerzak, M.; Rocheleau, H.; Leung, W.; Wei, Y.M.; Zheng, Y.L.; Ouellet, T. Jasmonic acid and abscisic acid play important roles in host-pathogen interaction between Fusarium graminearum and wheat during the early stages of Fusarium head blight. Physiol. Mol. Plant Pathol. 2016, 93, 39-48. [CrossRef]

28. Yoshida, T.; Christmann, A.; Yamaguchi-Shinozaki, K.; Grill, E.; Fernie, A.R. Revisiting the basal role of ABA-roles outside of stress. Trends Plant Sci. 2019, 24, 625-635. [CrossRef]

29. Yan, Y.; Zhang, X.; Zheng, X.; Apaliya, M.T.; Yang, Q.; Zhao, L.; Gu, X.; Zhang, H. Control of postharvest blue mold decay in pears by Meyerozyma guilliermondii and its effects on the protein expression profile of pears. Postharvest Biol. Technol. 2018, 136, 124-131. [CrossRef] 
30. Brown, P.; Saa, S. Biostimulants in agriculture. Front. Plant Sci. 2015, 6, 671. [CrossRef]

31. Anjum, S.A.; Wang, L.C.; Farooq, M.; Hussain, M.; Xue, L.L.; Zou, C.M. Brassinolide application improves the drought tolerance in maize through modulation of enzymatic antioxidants and leaf gas exchange. J. Agron. Crop Sci. 2011, 197, 177-185. [CrossRef]

32. Beccari, G.; Covarelli, L.; Nicholson, P. Infection processes and soft wheat response to root rot and crown rot caused by Fusarium culmorum. Plant Pathol. 2011, 60, 671-684. [CrossRef]

33. Kang, Z.; Buchenauer, H. Ultrastructural and immunocytochemical investigation of pathogen development and host responses in resistant and susceptible wheat spikes infected by Fusarium culmorum. Physiol. Mol. Plant Pathol. 2011, 57, 255-268. [CrossRef]

34. Wang, Q.; Shao, B.; Shaikh, F.I.; Friedt, W.; Gottwald, S. Wheat resistances to Fusarium root rot and head blight are both associated with deoxynivalenol-and jasmonate-related gene expression. Phytopathology 2018, 108, 602-616. [CrossRef] [PubMed]

35. Zobiole, L.H.S.; Kremer, R.J.; de Oliveira, R.S., Jr.; Constantin, J. Glyphosate effects on photosynthesis, nutrient accumulation, and nodulation in glyphosate-resistant soybean. J. Plant Nutr. Soil Sci. 2012, 175, 319-330. [CrossRef]

36. Takahama, U.; Oniki, T. Flavonoids and some other phenolics as substrates of peroxidase: Physiological significance of the redox reactions. J. Plant Res. 2000, 113, 301-309. [CrossRef]

37. Steyn, W.J.; Wand, S.J.E.; Holcroft, D.M.; Jacobs, G. Anthocyanins in vegetative tissues: A proposed unified function in photoprotection. New Phytol. 2002, 155, 349-361. [CrossRef]

38. Cartelat, A.; Cerovic, Z.G.; Goulas, Y.; Meyer, S.; Lelarge, C.; Prioul, J.L.; Barbottin, A.; Jeuffroy, M.H.; Gate, P.; Agati, G.; et al. Optically assessed contents of leaf polyphenolics and chlorophyll as indicators of nitrogen deficiency in wheat (Triticum aestivum L.). Field Crop. Res. 2005, 91, 35-49. [CrossRef]

39. Kangasjärvi, S.; Neukermans, J.; Li, S.; Aro, E.M.; Noctor, G. Photosynthesis, photorespiration, and light signalling in defence responses. J. Exp. Bot. 2012, 63, 1619-1636. [CrossRef]

40. Bauriegel, E.; Giebel, A.; Herppich, W.B. Rapid Fusarium head blight detection on winter wheat ears using chlorophyll fluorescence imaging. J. Appl. Bot. Food Qual. 2010, 83, 196-203.

41. Bauriegel, E.; Herppich, W.B. Hyperspectral and chlorophyll fluorescence imaging for early detection of plant diseases, with special reference to Fusarium spec. infections on wheat. Agriculture 2014, 4, 32-57. [CrossRef]

42. Sharma, A.; Kumar, V.; Shahzad, B.; Ramakrishnan, M.; Sidhu, G.P.S.; Bali, A.S.; Bakshi, P. Photosynthetic response of plants under different abiotic stresses: A review. J. Plant Growth Regul. 2019, 39, 509-531. [CrossRef]

43. Nantawanit, N.; Chanchaichaovivat, A.; Panijpan, B.; Ruenwongsa, P. Induction of defense response against Colletotrichum capsici in chili fruit by the yeast Pichia guilliermondii strain R13. Biol. Control 2010, 52, 145-152. [CrossRef]

44. Celis Zambrano, C.; Moreno Duran, G.; Sequeda-Castañeda, L.G.; García Caicedo, A.; Albarracín, D.M.; Barreto Charry, L.C. Determining the effectiveness of Candida guilliermondii in the biological control of Rhizopus stolonifer in postharvest tomatoes. Univ. Sci. 2014, 19, 51-62. [CrossRef]

45. Pordel, R. The Role of Plant Hormones in Fusarium Head Blight of Wheat. Ph.D. Dissertation, Department of Biological Sciences, University of Lethbridge, Lethbridge, AB, Canada, 2017.

46. Anderson, J.P.; Badruzsaufari, E.; Schenk, P.M.; Manners, J.M.; Desmond, O.J.; Ehlert, C.; Maclean, D.J.; Ebert, P.R.; Kazan, K. Antagonistic interaction between abscisic acid and jasmonate-ethylene signaling pathways modulates defense gene expression and disease resistance in Arabidopsis. Plant Cell 2004, 16, 3460-3479. [CrossRef] [PubMed]

47. Farooq, M.; Usman, M.; Nadeem, F.; ur Rehman, H.; Wahid, A.; Basra, S.M.; Siddique, K.H. Seed priming in field crops: Potential benefits, adoption and challenges. Crop. Pasture Sci. 2019, 70, 731-771. [CrossRef] 